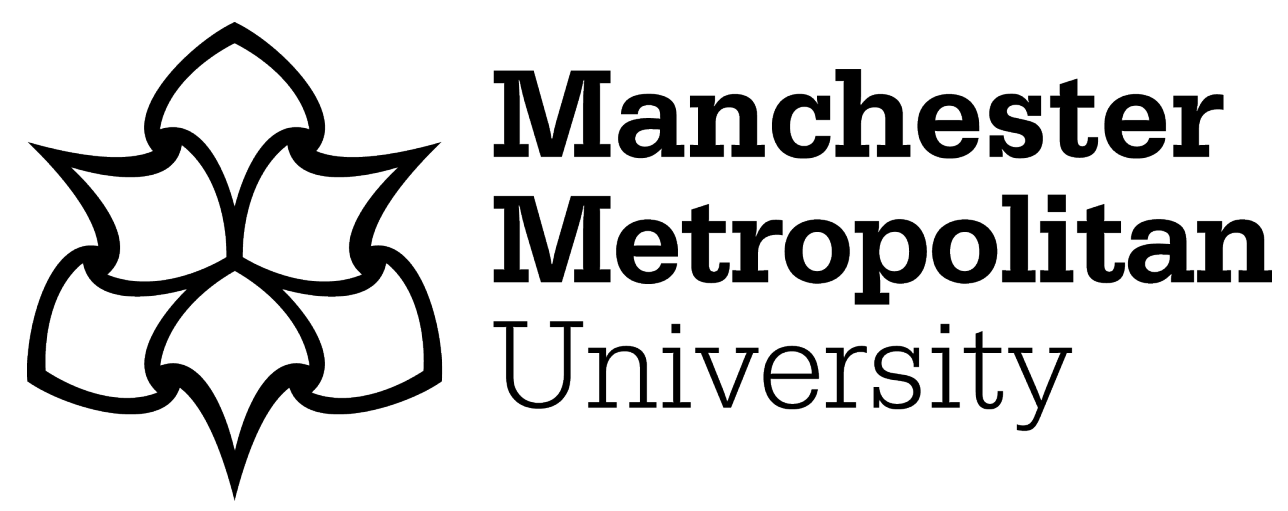

Alhabeeb, A and Rowley, J ORCID logoORCID: https://orcid.org/0000-00033437-6914 (2018) E-learning critical success factors: Comparing perspectives from academic staff and students. Computers and Education, 127. pp. 1-12. ISSN 0360-1315

Downloaded from: https://e-space.mmu.ac.uk/623233/

Version: Accepted Version

Publisher: Elsevier

DOI: https://doi.org/10.1016/j.compedu.2018.08.007

Usage rights: Creative Commons: Attribution-Noncommercial-No Derivative Works 4.0

Please cite the published version 


\title{
E-learning Success Factors: comparing perspectives from academic staff and students
}

\begin{abstract}
This article advances knowledge on the factors that lead to successful e-learning in universities, through a comparative study of the perspectives of academic staff and students. In particular, it contributes to the limited knowledge bases on the effectiveness of e-learning in Saudi Arabia, and on the differences in perspectives of different groups of stakeholders in e-learning. Based on previous research, a questionnaire was designed and distributed to convenience samples of academic staff and students at King Saud University, Saudi Arabia. Respondents were invited to express their opinion regarding the importance of a number of factors to the success of elearning. Principal Component Analysis was conducted on each dataset, in turn, to assess the loading of items onto factors, and the variance explained. The most important finding from this study is that the perspectives of students and academic staff differ, with there being nine factors for academic staff and seven for students. Categories that are common to both groups are: student characteristics, instructor characteristics, ease of access, and support and training. The order for academics is: student characteristics, ease of access, instructor characteristics, and support and training; and, the order foe students is: instructor characteristics, student characteristics, support and training, and ease of access.
\end{abstract}

Keywords: interactive learning environments; adult learning; country-specific developments

\section{Introduction}

E-learning has been implemented in many universities in different countries (Garrison, 2011). Sangrà, Vlachopoulos \& Cabrera (2012, p.152) define e-learning as: "an approach to teaching and learning, representing all or part of the educational model applied, that is based on the use of electronic media and devices as tools for improving access to training, communication and interaction and that facilitates the adoption of new ways of understanding and developing learning”. E-learning systems provide learning opportunities that are free from the constraints of place and time, and support new teaching and learning approaches. E-learning includes learning that is fully dependent on the e-learning system, as well as blended learning, involving a mix of traditional learning methods and e-learning. 
Despite the significant investment in e-learning systems in both developed and developing countries, the level of use of these systems by academics and their students is often low (Bhuasiri et al., 2012; Ssekakubo, Suleman \& Marsden, 2011). A number of researchers have sought to contribute to solving this issue by research that focusses on the factors that affect the adoption of e-learning (e.g. Boateng et al.,2016; King \& Boyatt, 2015) or user satisfaction with the e-learning system (González-Gómez et al., 2012; Sun et al., 2008; Teo \& Wong, 2013). Other researchers have sought to identify the impact of e-learning systems on student learning (e.g. Mohammadyari \& Singh, 2015). An alternative approach to the evaluation of the experience of e-learning, that also has the potential to inform an agenda for further development of e-learning systems, is to explore the critical success factors (CSF's) or the characteristics of e-learning systems that, from the user perspective, contribute to their success. The concept of critical success factors has its roots in the organisational strategy literature. CSFs are the most important factors that should be managed in order to enhance the chances of project and/or organisational success. Bruno and Leidecker (1984: 24) define CSFs as "characteristics, conditions or variables that, when properly sustained, maintained, or managed, can have a significant impact on the success of a firm competing in a particular industry”. The strength of a CSF approach to evaluation is that it can generate a clear agenda for the management and enhancement of a phenomenon (Sun et al., 2008).

A limited number of studies have sought to identify e-learning CSF's. These studies have been conducted in a wide range of contexts including schools (e.g. Taha, 2014) and universities (e.g. Selim, 2007; Puri, 2012). In addition, the country in which the studies have been conducted varies significantly. Of particular relevance to this study are the three prior studies in Saudi Arabia. Two of these focus on the technical side of e-learning systems (Alhomod and Alshafi, 2012; AlTameem, 2013), leaving Fryan and Sterigioulas's (2012) study as the only important predecessor to this study that was conducted in Saudi Arabia. In addition, the e-learning stakeholder groups considered in previous studies varies. Most focus on student perspectives (e.g. Musa \& Othman, 2012; Puri, 2012; Selim, 2007). Other researchers consider academic staff perspectives (e.g. Ahmed, 2013, Naveed et al., 2017), but only Taha (2014) and AbedGawad (2015) consider the perspectives of both groups. Hence, the research questions that this study seeks to address are:

- What do academic staff perceive to be the factors that affect the success of elearning? 
- What do students perceive to be the factors that affect the success of e-learning?

- Are there any differences between students' perceptions of CSF's and those of academic staff?

More specifically, this research:

- Identifies and provides a ranking of the e-learning CSF's for students at a major university in Saudi Arabia

- Identifies and provides a ranking of the e-learning CSF's for academic staff at a major university in Saudi Arabia

- Undertakes a critical comparison of these two sets of CSFs

- Offers recommendations for enhancing the success of e-learning.

\section{Context}

This study is based in Saudi Arabia. Saudi Arabia is a large country with a significant and growing higher education system (Aljubaili, 2014). In particular, the Saudi government has been proactive in supporting the development of eLearning for students on traditional courses and for those engaged in distance learning courses (Al-Dosari, 2011). In 2005, the National Centre of ELearning and Distance Learning (NCEDL) was established by the Ministry of Higher Education. The NCEDL encourages Saudi universities and helps them in their efforts to adopt and implement their eLearning systems. It also supports the digitalization of print resources such as books, and other learning resources (Al-Dosari, 2011). Universities have responded positively to government and NCEDL initiatives and many are proactively embedding e-Learning in their educational processes.

King Saud University (KSU) was chosen as the case context for this research. KSU is one of the largest and oldest universities in Saudi Arabia, and was one of the first Saudi universities to implement an eLearning system. The university was established in 1957 by King Saud bin Abdul-Aziz as Riyadh University, but was renamed King Saudi University in 1982. The university was the first university to be established in the Saudi Arabia Kingdom (KSU, 2017). Since 2014, the total number of registered students at the university exceeded $61,000.60 \%$ of students are male, and the rest female. The university employees around 5000 academic staff, of whom $63 \%$ are male. 
According to Abouzahra, (2011), KSU has deployed several technologies as part of their eLearning system including Blackboard, virtual classrooms, Learning Management Systems (LMS), class recording facilities, and online examination facilities. The eLearning system implemented in KSU serves on campus, off campus, and distance students. The system is also implemented throughout the colleges, departments, and deanships in the university. A dedicated deanship was established in 2010 to supervise the implementation and supervision of any eLearning systems related project. Moreover, the university was awarded a United Nations prize for successfully implementation of their eLearning system (KSU, 2010) and United Nations Public Service Awards, 2010).

\section{Literature review}

\subsection{Prior studies on e-learning CSF's}

There are a limited number of prior studies that have sought to identify e-learning CSF's. These studies are have been conducted in a wide range of different contexts. For example, some studies are based in schools (e.g Menchaca \& Bekele, 2008; Taha, 2014;), and others in universities (e.g. Abed-Gawad \& Woollard, 2015; Musa \& Othman, 2012; Paechter, Naier \& Macher, 2009; Puri, 2012; Selim, 2007). In addition, the country in which the study has been conducted varies significantly. For example, Selim (2007), studied student perspectives on elearning CSFs in United Arab Emirates, whilst Puri (2012), Musa \& Othman (2012), Paechter et al., (2009), and Abdel-Gawad \& Woollard (2015) studied students' perspectives in India, Australia, Malaysia, and Egypt, respectively.

Most importantly, for the purposes of this study, the participants in the studies vary. For example, most of the studies listed in the previous sentence focused on student perspectives. Other studies consider the perspectives of academic staff (e.g. Ahmed, 2013; Naveed et al., 2017. There are also some studies that consider the views of more than one group. For example, Taha (2014) and Abdel-Gawad (2015) investigated students' and teachers' perspectives, whilst Bhuasiri et al.(2012) studied ICT experts' and faculty members' perspectives and FitzPatrick \& Thaddeus (2012) used included students, teachers and e-learning experts. The factors considered by the most informative of these studies are summarized in Table 1. This table shows that there is some consensus with respect to the clusters of CSF's, even if some authors use slightly different terminology for these groups. These clusters are: instructor characteristics, student characteristics, technology infrastructure, e-learning systems and online learning resources, and support and training. On the other hand, there is a considerable variation 
in the number of and actual individual factors studied and/or identified by the various authors. Accordingly, there is scope for further studies to investigate the CSF's for e-learning. In addition, the studies that have conducted an evaluation of CSF's for two different groups using the same e-learning system in the same university or other educational setting have shown that there are differences between the two groups in the specific factors that they see as being associated with success. For example, in investigating the factors that impact on e-learning implementation in Bahraini secondary schools, Taha (2014) some differences between the two samples in relation to the categories: teachers' characteristics, technology, and design and content. Bhuasiri et al. (2012) investigated ICT experts and faculty members' perspectives in developing countries; they also found differences between the two groups. Their results have shown differences between the two groups in terms of the dimensions (categories of factors) and the ranking of the factors themselves. For example, the ICT experts' results showed that learner characteristics are the most important category of factors for the success of the eLearning system while faculty members regarded Infrastructure and system quality as the most important category. In terms of actual factors, ICT experts ranked computer training, perceived usefulness, attitude toward e-learning, computer self-efficacy, and program flexibility as the most important factors for the success of the system. On the other hand, perceived usefulness, attitude toward eLearning, program flexibility, clear direction, and course quality are the most important factors from faculty members' point of view.

\subsection{Studies in Saudi Arabia on e-learning CSF's}

In Saudi Arabian context, very limited research has been done to identify eLearning CSFs. The most wide-ranging study of e-learning CSF's in Saudi Arabia, was conducted six years ago by Fryan and Stergioulas (2011) has focused on investigating CSFs of eLearning systems in five Saudi academic institutions. Using mixed research methods (questionnaire and interviews), they attempted to identify eLearning CSFs from student and instructor perspectives in five Saudi Arabian universities. They identified four categories of eLearning, which together contained 52 different factors. However, despite being the most comprehensive and important research that attempted to identify eLearning CSFs in a Saudi context, nevertheless, Fryan and Stergioulas's (2012) research did not order these categories.

Two other studies (AlTameem, 2013; Alhomod and Alshafi, 2013) have also attempted to identify eLearning CSFs. AlTameem (2013) has focused on the technical side of eLearning system when he attempted to identify the technical factors which impact the implementation 
of an eLearning system. AlTameem (2013) has followed qualitative research methods and his research resulted on identifying three main factors and they are the reliability of Information and communications Technology (ICT), the implemented security systems, and the available technical support for the users of the system. From a wider scope, Alhomod and Alshafi (2012) have also focused on the technical side of eLearning systems by involving the perspectives of system management and users. According to the results of their research, the most important factors are those concerning users training, organisation commitment, management support, technical support, positive attitude of users, easy to use tools, sufficient training for engineers, sufficient eLearning initiatives, sufficient manpower, availability of information on the eLearning website, support from other departments.

\subsection{Summary and contribution}

The various studies discussed above have identified a number of CSF's relating to e-Learning and have grouped them into various categories. The categories and the specific CSF's vary between studies, but there are some common patterns. Table 1 summarises these CSF's into five main categories that emerge from the literature. Against each category, the authors that mention CSF's in that category are identified. Not all authors necessarily included each of the identified factors in this table. This list was used as a basis for the questionnaire survey design, with both academic staff and students. 


\begin{tabular}{|c|c|c|c|c|c|c|c|c|c|c|c|c|c|}
\hline 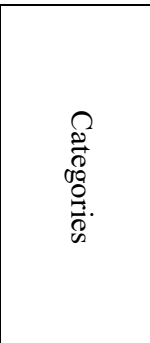 & Sources & 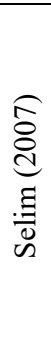 & 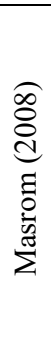 & 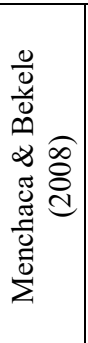 & 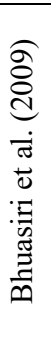 & 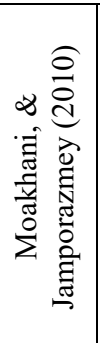 & 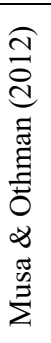 & 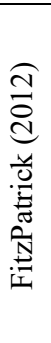 & $\begin{array}{l}\text { త্ } \\
\stackrel{d}{d} \\
\vdots \\
\vdots \\
\vdots\end{array}$ & 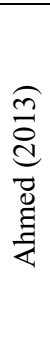 & 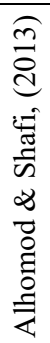 & 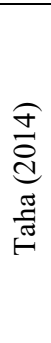 & 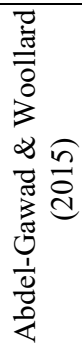 \\
\hline \multirow{7}{*}{ 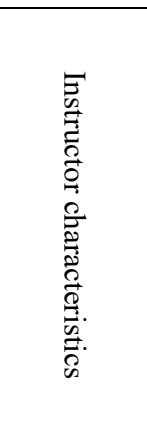 } & 1. Instructor's enthusiasm while teaching using eLearning tools & $\sqrt{ }$ & & & & $\sqrt{ }$ & & & $\sqrt{ }$ & $\sqrt{ }$ & & & $\sqrt{ }$ \\
\hline & $\begin{array}{l}\text { 2. Instructor's ability to motivate the students to use the eLearning } \\
\text { system }\end{array}$ & $\sqrt{ }$ & & $\sqrt{ }$ & & $\sqrt{ }$ & & & & & & $\sqrt{ }$ & \\
\hline & 3. The clarity of instructor's explanation of the eLearning components & $\sqrt{ }$ & & & & & & & $\sqrt{ }$ & $\sqrt{ }$ & & & \\
\hline & 4. Instructor's ability to use the eLearning system effectively & $\sqrt{ }$ & & $\sqrt{ }$ & $\sqrt{ }$ & $\sqrt{ }$ & & & $\sqrt{ }$ & & & $\sqrt{ }$ & \\
\hline & 5. Instructor's style of teaching using eLearning technologies. & $\sqrt{ }$ & & & & & & & & $\sqrt{ }$ & & $\sqrt{ }$ & \\
\hline & 6. Instructor's friendliness in general and while teaching & $\sqrt{ }$ & & & $\sqrt{ }$ & & & & $\sqrt{ }$ & & & & \\
\hline & $\begin{array}{l}\text { 7. Instructor's ability to motivate students to get engaged in online } \\
\text { discussions }\end{array}$ & $\sqrt{ }$ & & $\sqrt{ }$ & $\sqrt{ }$ & & $\sqrt{ }$ & & $\sqrt{ }$ & $\sqrt{ }$ & & & \\
\hline \multirow{6}{*}{ 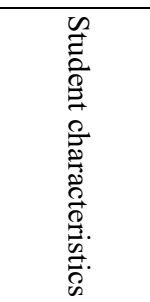 } & 1. Students' willingness to participate in e-learning & $\sqrt{ }$ & & $\sqrt{ }$ & $\sqrt{ }$ & & $\sqrt{ }$ & & $\sqrt{ }$ & $\sqrt{ }$ & & & \\
\hline & 2. The student's learning style affecting the use of eLearning. & $\sqrt{ }$ & & & & & $\sqrt{ }$ & & & $\sqrt{ }$ & & & $\sqrt{ }$ \\
\hline & 3. The student's ability to find things in eLearning system & & & & & & $\sqrt{ }$ & & $\sqrt{ }$ & & & $\sqrt{ }$ & $\sqrt{ }$ \\
\hline & 4. Student's experience and knowledge about computers & $\sqrt{ }$ & & $\sqrt{ }$ & $\sqrt{ }$ & & $\sqrt{ }$ & & $\sqrt{ }$ & $\sqrt{ }$ & & & \\
\hline & 5. The level of student's enjoyment while using technology & $\sqrt{ }$ & & & & & $\sqrt{ }$ & & $\sqrt{ }$ & & & $\sqrt{ }$ & \\
\hline & $\begin{array}{l}\text { 6. The student's understanding of the purpose of different parts of the } \\
\text { eLearning system }\end{array}$ & $\sqrt{ }$ & & & & $\sqrt{ }$ & $\sqrt{ }$ & & $\sqrt{ }$ & $\sqrt{ }$ & & & $\sqrt{ }$ \\
\hline \multirow{8}{*}{ 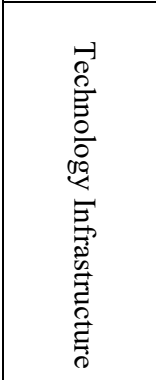 } & 1. Easy access to internet & $\sqrt{ }$ & $\sqrt{ }$ & & $\sqrt{ }$ & $\sqrt{ }$ & $\sqrt{ }$ & $\sqrt{ }$ & & $\sqrt{ }$ & & & \\
\hline & 2. Browsing is easy & $\sqrt{ }$ & $\sqrt{ }$ & $\sqrt{ }$ & $\sqrt{ }$ & & $\sqrt{ }$ & & $\sqrt{ }$ & & & & \\
\hline & 3. Availability of online communication tools. & $\sqrt{ }$ & $\sqrt{ }$ & $\sqrt{ }$ & $\sqrt{ }$ & & & $\sqrt{ }$ & & $\sqrt{ }$ & & & \\
\hline & 4. Internet speed & $\sqrt{ }$ & $\sqrt{ }$ & & & $\sqrt{ }$ & $\sqrt{ }$ & $\sqrt{ }$ & $\sqrt{ }$ & & & & \\
\hline & 5. Availability of multimedia tools/technologies & & & $\sqrt{ }$ & & & & & $\sqrt{ }$ & $\sqrt{ }$ & & & \\
\hline & 6. Ability to search for learning material using the website & $\sqrt{ }$ & & & & & $\sqrt{ }$ & $\sqrt{ }$ & & & & & $\sqrt{ }$ \\
\hline & 7. Availability of sufficient computer labs & $\sqrt{ }$ & $\sqrt{ }$ & & $\sqrt{ }$ & & $\sqrt{ }$ & & & $\sqrt{ }$ & & & \\
\hline & 8. Reliable technical infrastructure. & $\sqrt{ }$ & $\sqrt{ }$ & & $\sqrt{ }$ & $\sqrt{ }$ & $\sqrt{ }$ & $\sqrt{ }$ & $\sqrt{ }$ & $\sqrt{ }$ & & $\sqrt{ }$ & $\sqrt{ }$ \\
\hline sa & 1. Ease of registration on e-learning course & $\sqrt{ }$ & & $\sqrt{ }$ & & & $\sqrt{ }$ & & & $\sqrt{ }$ & & & \\
\hline
\end{tabular}




\begin{tabular}{|c|c|c|c|c|c|c|c|c|c|c|c|c|c|}
\hline 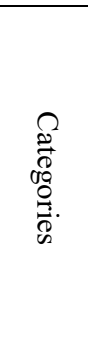 & Factors & 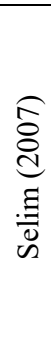 & 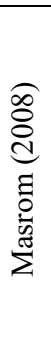 & 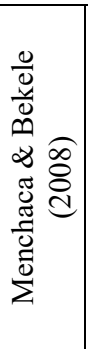 & 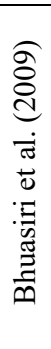 & 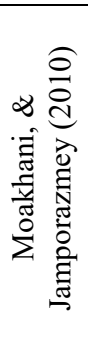 & 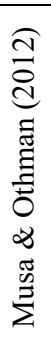 & 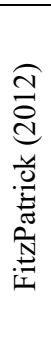 & $\begin{array}{l}\text { I } \\
\text { d } \\
\stackrel{\Xi}{\Xi} \\
0\end{array}$ & 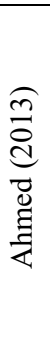 & 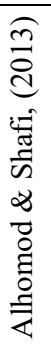 & 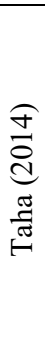 & 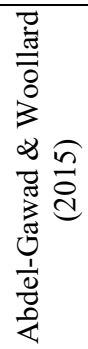 \\
\hline & 2. Access to the e-learning resources on and off campus & $\sqrt{ }$ & & & & & $\sqrt{ }$ & & & $\sqrt{ }$ & & $\sqrt{ }$ & \\
\hline & 3. The layout and design of information & $\sqrt{ }$ & & $\sqrt{ }$ & & $\sqrt{ }$ & $\sqrt{ }$ & $\sqrt{ }$ & $\sqrt{ }$ & & & $\sqrt{ }$ & \\
\hline & 4. Ease of learning material preparation & $\sqrt{ }$ & & & & & & & & & & & \\
\hline & 5. Language Support & $\sqrt{ }$ & & & $\sqrt{ }$ & & & $\sqrt{ }$ & $\sqrt{ }$ & $\sqrt{ }$ & & & $\sqrt{ }$ \\
\hline & 6. Sufficiency of the learning materials & $\sqrt{ }$ & & & $\sqrt{ }$ & $\sqrt{ }$ & & & & $\sqrt{ }$ & $\sqrt{ }$ & $\sqrt{ }$ & \\
\hline & 7. Course interactivity & $\sqrt{ }$ & & $\sqrt{ }$ & & $\sqrt{ }$ & $\sqrt{ }$ & $\sqrt{ }$ & $\sqrt{ }$ & & & & \\
\hline & $\begin{array}{l}\text { 8. Availability of communications with the instructor in the eLearning } \\
\text { system }\end{array}$ & $\sqrt{ }$ & & $\sqrt{ }$ & & & $\sqrt{ }$ & $\sqrt{ }$ & & $\sqrt{ }$ & & & \\
\hline & 9. Availability of online test/quizzes & & & & & & & & $\sqrt{ }$ & $\sqrt{ }$ & & & \\
\hline & 10.Option to return to unfinished tasks & & & & & & & & & $\sqrt{ }$ & & & \\
\hline & 11.Measurement of learning progress & $\sqrt{ }$ & & & & $\sqrt{ }$ & & $\sqrt{ }$ & & $\sqrt{ }$ & & & \\
\hline & 12.Whether the learning material is up-to-date & & & & & $\sqrt{ }$ & & $\sqrt{ }$ & & & & $\sqrt{ }$ & \\
\hline \multirow{5}{*}{ 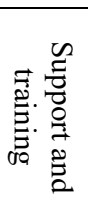 } & 1. Availability of offline technical support & $\sqrt{ }$ & $\sqrt{ }$ & $\sqrt{ }$ & & & & $\sqrt{ }$ & $\sqrt{ }$ & $\sqrt{ }$ & $\sqrt{ }$ & $\sqrt{ }$ & $\sqrt{ }$ \\
\hline & 2. Friendliness of support team & $\sqrt{ }$ & $\sqrt{ }$ & $\sqrt{ }$ & & $\sqrt{ }$ & & & $\sqrt{ }$ & & & & \\
\hline & 3. Availability of online help desk & & & $\sqrt{ }$ & & & & & & $\sqrt{ }$ & $\sqrt{ }$ & & \\
\hline & 4. Availability of training & & $\sqrt{ }$ & $\sqrt{ }$ & $\sqrt{ }$ & & & $\sqrt{ }$ & $\sqrt{ }$ & $\sqrt{ }$ & $\sqrt{ }$ & $\sqrt{ }$ & \\
\hline & 5. Availability of on campus printing facilities & $\sqrt{ }$ & $\sqrt{ }$ & & & & & & & $\sqrt{ }$ & & & \\
\hline
\end{tabular}

Table 1: eLearning CSFs from prior research 


\section{Methods}

\subsection{Participants}

Two related surveys were used to collect data to achieve the study objectives. Both surveys were conducted in King Saud University in Saudi Arabia, using convenience samples of academic staff and students, respectively. Data was gathered from 230 academic staff $(65.7 \%$ response rate) and 306 students (response rate 61.2\%). Whilst the final dataset is based on a convenience sample, the demographic statistics are broadly consistent with those of the population as described earlier in section 3.1.

Table 2 summarises academic staff sample in terms of age, gender, nationality, academic degree, and job title. It shows that most participants $(67 \%)$ have a $\mathrm{PhD}$, and that, with respect to job title, the biggest group are Assistant or Associate Professors (55\%). Also, the majority are Saudi nationals (89\%). Arguably, a little more interesting is the age of the academic staff, with 55\% in the 26-40 years old group. With regard to gender, more than two thirds of the staff are male, possibly a reflection of the Saudi culture where women's freedom to work is limited.

\begin{tabular}{|c|c|c|c|}
\hline & & Frequency & Percentage \\
\hline \multirow[t]{4}{*}{ Age } & Younger than 25 & 1 & 0.4 \\
\hline & 26 to 40 years & 128 & 54.9 \\
\hline & 41 to 55 years old & 72 & 30.9 \\
\hline & Over 55 years old & 32 & 13.7 \\
\hline \multirow[t]{2}{*}{ Gender } & Male & 160 & 68.7 \\
\hline & Female & 73 & 31.3 \\
\hline \multirow[t]{2}{*}{ Nationality } & Saudi & 206 & 88.8 \\
\hline & Non-Saudi & 26 & 11.2 \\
\hline \multirow{4}{*}{ Academic degree } & Less than bachelor & 0 & 0 \\
\hline & Bachelor degree & 15 & 6.4 \\
\hline & Master's degree & 61 & 26.2 \\
\hline & $\mathrm{PhD}$ & 157 & 67.4 \\
\hline \multirow{12}{*}{ Job title } & Instructor & 20 & 8.6 \\
\hline & Lecturer & 58 & 24.9 \\
\hline & Assistant professor & 84 & 30.1 \\
\hline & Associate professor & 57 & 24.5 \\
\hline & Professor & 14 & 6.0 \\
\hline & Education & 51 & 15.9 \\
\hline & Science & 46 & 14.4 \\
\hline & Arts & 54 & 16.9 \\
\hline & Economic and business Management & 23 & 7.2 \\
\hline & Food and Agricultural Sciences & 4 & 1.2 \\
\hline & Computer & 14 & 4.3 \\
\hline & Nursing & 2 & 0.06 \\
\hline
\end{tabular}




\begin{tabular}{|c|c|c|c|}
\hline \multirow{3}{*}{ Discipline } & Law and Political Science & 7 & 2.1 \\
\cline { 2 - 4 } & Pharmacy & 4 & 1.2 \\
\cline { 2 - 4 } & Medicine & 2 & 0.06 \\
\cline { 2 - 4 } & Architecture & 2 & 0.06 \\
\cline { 2 - 4 } & Languages and Translation & 5 & 1.5 \\
\cline { 2 - 4 } & Engineering & 14 & 4.3 \\
\cline { 2 - 4 } & Sports Science and Physical Activity & 1 & 0.3 \\
\cline { 2 - 4 } & Dentistry & 1 & 0.3 \\
\hline
\end{tabular}

Table 2: Academic staff demographic data

Table 3 summarises the student profile in terms of age, gender, nationality, academic degree for which they are studying, and their current year of study (e.g. first year, second year). This table shows that the majority of the participants are of Saudi nationality (99\%), and are undergraduates on years $2,3,4$, or 5 of their course $(75.6 \%)$, and, as such $77 \%$ are between the ages of 21 and 25 .

\begin{tabular}{|c|c|c|c|}
\hline & & Frequency & Percentage \\
\hline \multirow{4}{*}{ Age } & Younger than 20 & 6 & 2.0 \\
\cline { 2 - 4 } & 21 to 25 years old & 235 & 76.8 \\
\cline { 2 - 4 } & 26 to 30 years old & 42 & 13.7 \\
\cline { 2 - 4 } & Older than 30 & 23 & 7.5 \\
\hline \multirow{4}{*}{ Gender } & Male & 243 & 79.4 \\
\cline { 2 - 4 } & Female & 63 & 20.6 \\
\hline Nationality & Saudi & 302 & 98.7 \\
\cline { 2 - 4 } & Non-Saudi & 4 & 1.3 \\
\hline Academic degree & Bachelor & 289 & 94.4 \\
\cline { 2 - 4 } & Postgraduate & 17 & 5.6 \\
\hline Academic year & 1 & 19 & 6.3 \\
\cline { 2 - 4 } & $2-3$ & 110 & 36.3 \\
\cline { 2 - 4 } & $4-5$ & 119 & 39.3 \\
\cline { 2 - 4 } & More than fifth & 55 & 18.2 \\
\cline { 2 - 4 } & & & \\
\hline
\end{tabular}

Table 3: Student demographic data

\subsection{Procedure and materials}

Two questionnaires were designed for purpose of collecting the suitable data from the two study populations (students and academic staff). Questionnaire design was informed by the literature review which identified potential CSF's and their categorization (Table 1), together with an earlier study conducted by the authors on CSF's with e-learning experts; this study was also conducted in Saudi Arabia, but adopted a qualitative approach based on structured interviews. 
The two questionnaires are related in that, wherever appropriate, the two groups were asked the same questions, in order to maximize comparability. At the core of both questionnaires was a bank of five-point Likert-style statements each relating to an eLearning CSF, for which participants were invited to express their opinion regarding its importance to the success of elearning. One of the limitations of this study, and other studies on e-learning CSF's is that participants/ definitions of success may vary. A demographics section collects data about the respondents' demographics status. There are minor differences between the two questionnaires. For example the demographics data collected differs, and in the Likert-style statements terminology has been adapted to reflect the participants' role (staff or student). For example, in the student characteristics section, questions used "my" before the main question statement; for example; "my enthusiasm to use the eLearning system". In addition, the questionnaires start with a general introduction that is tailored to the respondent population (e.g. students or academic staff).

To ensure that the questionnaires were fit for purpose two pilot studies were conducted. The first pilot study used an English language version of the questionnaire to collect data from a sample of five Saudi students and four Saudi academic staff who are currently studying in the UK. As a result, eight questions were in corrected or clarified. The second pilot was based on an Arabic version of the questionnaire, which was distributed to fifty members of the actual study population. 21 students and 12 academic staff complete the questionnaire. In this stage, five additional questions were either clarified or removed. For example, the respondents were asked about the reliability of the computer networks in their institution; however, as respondents felt that this question was covered under another question that asked them about the reliability of the computer infrastructure in general, this question has been removed. In another question, reference to the 'currency' of the available learning material was reported to be unclear; this was changed so that it referred to the learning materials being 'up-to-date'. Nevertheless, it is acknowledged, that, as with all surveys, respondents may interpret questions differently.

\subsection{Data analysis}

Data was loaded into SPSS for analysis. A few incomplete questionnaires were removed. The remaining questionnaires were analysed. Descriptive statistics were generated for the demographic variables. In order to identify the factors that academic staff and students consider 
to be critical to the success of e-learning, by academic staff and students, two separate exploratory factor analyses were performed.

\section{Findings}

Once descriptive statistics had been generated, suitability of the dataset for Exploratory Factor Analysis (EFA) was established using the Kaiser-Meyer-Olkin (KMO) measure of sampling adequacy and Bartlett's Test of Sphericity. Both datasets had a KMO index above the acceptable minimum of 0.50 , and Barlett's test had a level of significance above the required level of $.05 \%$, and hence the data was deemed suitable for EFA (Table 4).

\begin{tabular}{|l|l|l|}
\hline \multicolumn{3}{|c|}{ Academic staff: KMO and Bartlett's Test } \\
\hline Kaiser-Meyer-Olkin Measure of Sampling Adequacy. & .898 \\
\hline \multirow{3}{*}{ Bartlett's Test of Sphericity } & Approx. Chi-Square & 3949.433 \\
\cline { 2 - 3 } & Df & 703 \\
\cline { 2 - 3 } & Sig. & 0.000 \\
\hline \multicolumn{3}{|c|}{ Students: KMO and Bartlett's Test } \\
\hline Kaiser-Meyer-Olkin Measure of Sampling Adequacy. & .886 \\
\hline \multirow{2}{*}{ Bartlett's Test of Sphericity } & Approx. Chi-Square & 4737.845 \\
\cline { 2 - 3 } & Df & 666 \\
\cline { 2 - 3 } & Sig. & 0.000 \\
\hline
\end{tabular}

Table 4: KMO and Bartlett's Test Data

Next, Principal Components Analysis (PCA) was used to identify the factors which explain most variance in the data sets. The extraction criterion used is that the cumulative Percentage of Variance and Eigenvalue for the factor to be identified (extracted) is $>1$. This resulted in the identification of nine factors for both the academic staff and student samples. Next, orthogonal varimax rotation was used to generate a component matrix, which shows the loading of items onto the identified factors for both data sets. All items with a loading value less than 0.5 , and all factors with less than two items loading onto were removed. This resulted in the removal of two factors from the original nine factors for the student sample. The final step of EFA analysis is to name the final factors in a way that reflects the nature the items loaded on it. Tables 6 and 7 show the final factors and the items loading onto them for both datasets. The nine academic staff factors explain a total of $62.6 \%$ of the variances in the data sets, and the seven student factors explain $64.4 \%$ of the variances. 


\begin{tabular}{|c|c|c|}
\hline Factor & Items & Component \\
\hline \multirow{5}{*}{$\begin{array}{c}\text { Student } \\
\text { characteristics }\end{array}$} & S3 The student's ability to find things in eLearning system & 0.721 \\
\hline & S4 Student's experience and knowledge about computers & 0.689 \\
\hline & $\begin{array}{l}\text { S2 The student's learning style affecting the use of } \\
\text { eLearning }\end{array}$ & 0.666 \\
\hline & S1 Students' willingness to participate in e-learning & 0.569 \\
\hline & S6 The student's understanding of the purpose & 0.542 \\
\hline \multirow{4}{*}{$\begin{array}{c}\text { E-learning } \\
\text { system }\end{array}$} & E5 Language Support & 0.669 \\
\hline & T6 Ability to search for learning material using the website & 0.591 \\
\hline & T4 Internet speed & 0.589 \\
\hline & E4 Ease of learning material preparation & 0.545 \\
\hline \multirow[t]{3}{*}{ Experience } & E7 Course interactivity & 0.634 \\
\hline & $\begin{array}{l}\text { E8 Availability of communications with the instructor in the } \\
\text { eLearning system }\end{array}$ & 0.633 \\
\hline & T8 Reliable technical infrastructure & 0.589 \\
\hline \multirow[t]{3}{*}{ Ease of access } & T1 Easy access to internet & 0.787 \\
\hline & T2 Browsing is easy & 0.760 \\
\hline & T3 Availability of online communication tools (e.g.e-mail) & 0.620 \\
\hline \multirow[t]{5}{*}{$\begin{array}{c}\text { Instructor } \\
\text { characteristics }\end{array}$} & $\begin{array}{l}\text { I3 The clarity of my explanation of the eLearning } \\
\text { components }\end{array}$ & 0.717 \\
\hline & $\begin{array}{l}\text { I } 2 \text { My ability to motivate the students to use the eLearning } \\
\text { system }\end{array}$ & 0.705 \\
\hline & I1 My enthusiasm while teaching using eLearning tools & 0.638 \\
\hline & I5 My style of teaching using eLearning technologies & 0.606 \\
\hline & I4 My ability to use the eLearning system effectively & 0.566 \\
\hline \multirow{3}{*}{$\begin{array}{c}\text { Ease of use of } \\
\text { eLearning } \\
\text { support }\end{array}$} & E1 Ease of registration on e-learning course. & 0.682 \\
\hline & E2 Access to the e-learning resources on and off campus & 0.682 \\
\hline & E3 The layout and design of information & 0.670 \\
\hline \multirow{3}{*}{$\begin{array}{l}\text { Support and } \\
\text { training }\end{array}$} & ST3 Availability of online help desk & 0.786 \\
\hline & ST2 Friendliness of support team & 0.722 \\
\hline & ST4 Availability of training & 0.686 \\
\hline \multirow{3}{*}{$\begin{array}{c}\text { E-learning } \\
\text { tools }\end{array}$} & E11 Measurement of learning progress & 0.680 \\
\hline & $\begin{array}{l}\text { I7 My ability to motivate students to get engaged in online } \\
\text { discussions }\end{array}$ & 0.649 \\
\hline & E9 Availability of online test/quizzes. & 0.547 \\
\hline \multirow[t]{2}{*}{ Engagement } & S5 The level of student's enjoyment while using technology & 0.649 \\
\hline & I6 My friendliness in general and while teaching & 0.631 \\
\hline
\end{tabular}

Table 5: Final Academic Staff Factors 


\begin{tabular}{|c|c|c|}
\hline Factor & Items & Component \\
\hline \multirow{5}{*}{$\begin{array}{l}\text { Technology } \\
\text { Infrastructure }\end{array}$} & T2 Browsing is easy & 0.789 \\
\hline & T1 Easy access to internet & 0.711 \\
\hline & T3 Availability of online communication tools (e.g.-mail) & 0.684 \\
\hline & T7 Availability of sufficient computer labs & 0.642 \\
\hline & T8 Reliable technical infrastructure & 0.527 \\
\hline \multirow[t]{5}{*}{$\begin{array}{c}\text { Instructor } \\
\text { characteristics }\end{array}$} & $\begin{array}{l}\text { I1 Instructor's enthusiasm while teaching using eLearning } \\
\text { tools }\end{array}$ & 0.751 \\
\hline & $\begin{array}{l}\text { I2 Instructor's ability to motivate the students to use the } \\
\text { eLearning system }\end{array}$ & 0.740 \\
\hline & I4 Instructor's ability to use the eLearning system effectively & 0.739 \\
\hline & $\begin{array}{l}\text { I3 The clarity of instructor's explanation of the eLearning } \\
\text { components }\end{array}$ & 0.718 \\
\hline & I5 Instructor's style of teaching using eLearning technologies & 0.674 \\
\hline \multirow{6}{*}{$\begin{array}{c}\text { Student } \\
\text { characteristics }\end{array}$} & S3 My ability to find things in eLearning system & 0.700 \\
\hline & $\begin{array}{l}\text { S6 My understanding of the purpose of different parts of the } \\
\text { eLearning system }\end{array}$ & 0.664 \\
\hline & S4 My experience and knowledge about computers & 0.661 \\
\hline & S5 The level of my enjoyment while using technology & 0.659 \\
\hline & S2 My learning style is affecting my use of eLearning & 0.637 \\
\hline & S1 My willingness to participate in e-learning & 0.635 \\
\hline \multirow{5}{*}{$\begin{array}{l}\text { eLearning } \\
\text { systems } \\
\text { resources }\end{array}$} & E8 Availability of online test/quizzes. & 0.729 \\
\hline & $\begin{array}{l}\text { E7 Availability of communications with the instructor in the } \\
\text { eLearning system }\end{array}$ & 0.636 \\
\hline & E6 Course interactivity & 0.602 \\
\hline & E10 Measurement of learning progress & 0.532 \\
\hline & E11 Whether the learning material is up-to-date. & 0.507 \\
\hline \multirow{4}{*}{$\begin{array}{l}\text { Support and } \\
\text { training. }\end{array}$} & ST4 Availability of training & 0.722 \\
\hline & ST3 Availability of online help desk & 0.679 \\
\hline & ST1 Availability of offline technical support & 0.670 \\
\hline & ST2 Friendliness of support team & 0.523 \\
\hline \multirow[t]{2}{*}{ Ease of access } & E1 Ease of registration on e-learning course & 0.715 \\
\hline & E2 Access to the e-learning resources on and off campus & 0.688 \\
\hline \multirow{2}{*}{$\begin{array}{l}\text { Searching } \\
\text { support }\end{array}$} & E4 Language Support & 0.702 \\
\hline & T6 Ability to search for learning material using the website & 0.536 \\
\hline
\end{tabular}

Table 6: Final Student Factors

\section{Discussion}

The aim of this study was to identify the CSF's associated with e-learning, and to investigate whether the factors are the same for both academic staff and students. As such, it contributes to the limited knowledge bases on the effectiveness of e-learning in Saudi Arabia, as well as that on the differences in perspectives in different groups of stakeholders of e-learning. 
Accordingly, the most important finding from this study is that the perspectives of students and academic staff differ. The identification and acknowledgement of the different perspectives should prompt decision makers to consider the two perspectives. Failure to satisfy either perspectives could lead to unusable or desirable e-learning systems.

While the starting questionnaires were almost identical in terms of factors and their associated items, the results of EFA have shown a difference in the perceptions of these two groups in terms of how they view CSFs associated with eLearning systems. The most noticeable difference is the difference in the number of factors for the two groups, viz, nine for academic staff and seven for students. This difference in numbers of factors could be related to the greater level of experience that academic staff have with e-learning systems, and is an indication of their more sophisticated decision processes. Nevertheless, there are a number of categories that are common to both groups; these are: student characteristics, instructor characteristics, ease of access, and support and training. In addition, there are two other factors that are similar, but not identical between the two groups: e-learning system (academic staff) and technology infrastructure (students). Finally, the relative ranking of factors varies between the groups, with, for academic staff the most important three critical success factors (in order of importance reflected by the percentage variance they explain) being: student characteristics, e-learning system, and the experience of the system. The following table shows the different categories for academic staff sample and the total variance each category explained.

\begin{tabular}{|c|c|c|}
\hline \multicolumn{3}{|c|}{ Total Variance Explained } \\
\hline Component & Factor label & \% of Variance \\
\hline 1 & Student characteristics & 28.5 \\
\hline 2 & E-learning system & 8.1 \\
\hline 3 & Experience & 5.4 \\
\hline 4 & Ease of access & 4.30 \\
\hline 5 & Instructor characteristics & 3.80 \\
\hline 6 & Ease of use of eLearning support & 3.38 \\
\hline 7 & Support and training & 3.36 \\
\hline 8 & E-learning tools & 3.00 \\
\hline 9 & Engagement & 2.76 \\
\hline Total & - & 62.6 \\
\hline
\end{tabular}

Table 7: Academic staff component matrix

For students, the most important three CSF's (in order of importance) are: technology infrastructure, instructor characteristics, and student characteristics. 
The factors that each group regards as the most important is a significant indicator of their perspective on e-learning systems. For example, academic staff are in the role of teachers, and therefore prioritize student characteristics over other factors. Or, in other words, whilst they acknowledge the importance of the characteristics of the learning system, they regard the students and their interaction with that system as being of prime importance. On the other hand, in prioritizing the technology infrastructure, students are reflecting on their own experience with the technology - and are prioritizing factors such as easy browsing, easy access to the internet, availability of sufficient computer labs, and reliability. They also regard instructor characteristics, including instructors' enthusiasm, and competence regarding the e-learning system to be an important supporting factor.

\begin{tabular}{|c|c|c|}
\hline \multicolumn{3}{|c|}{ Total Variance Explained } \\
\hline Component & Factor label & \% of Variance \\
\hline 1 & Technology Infrastructure & 27.40 \\
\hline 2 & Instructor characteristics & 7.70 \\
\hline 3 & Student characteristics & 5.24 \\
\hline 4 & eLearning systems resources & 4.92 \\
\hline 5 & Support and training. & 4.00 \\
\hline 6 & Ease of access & 3.50 \\
\hline 7 & Searching support & 3.04 \\
\hline Total & - & 61.46 \\
\hline
\end{tabular}

Table 8: Students component matrix

Such insights are not available from earlier studies, since most of these studies have focused on the student perspective (Selim, 2007; Puri, 2012; Abdel-Gawad and Woollard, 2015). Those studies that have included students and teachers have done so in specific contexts, such as schools (Taha, 2014) and distance learning (Menchaca and Bekele, 2008).

Another important observation on the findings from this study relates to the CSF's identified. These are, like many previous studies, unique. Most other studies on e-learning CSFs generate categories of factors, but these categories vary considerably between studies. For example, Selim (2007) identified seven factors, with three focusing on student characteristics, and the other four being instructors' characteristics, technology, support and eLearning system. Taha (2014) identify the following four categories: students' characteristics, teachers' characteristics, technology, and design and content. Abdel-Gawad and Woollard (2015) and resulted identified four categories of eLearning CSFs: tutors' characteristics, learners' characteristics, and technology, and curriculum nature. Whilst there are some recurrent 
categories, there is no consensus on the CSF's for e-learning. There are a number of potential reasons for this, including differences in research aims and objectives, difference in research approach (e.g. quantitative v qualitative), date of research, and country and culture of the study sample. In addition, where there is some agreement on categories, there remain differences in the relative ranking of CSF's. Overall, there is evident scope for further research into CSFs for e-learning, both in Saudi Arabia and in other countries.

\section{Conclusions}

This research makes a useful contribution to understanding the factors that might affect the success of e-learning, and can be used to inform government and university policy making regarding investment in e-learning. Being well-informed regarding what matters and is important when designing and implementing an eLearning system is vital for the success of these systems. In addition to the saving of the institution resources (funds, time, and labour), having a successful eLearning system can impact the image of the higher educational institution (Taha, 2014). In particular, given the different perspectives of students and academic staff it is important for those involved in the implementation of e-learning systems to consider the perspectives of all stakeholders and user groups and not to assume that the 'success' for one group implies 'success' for another group. Academic staff can benefit from this study by understanding the students' perspective on eLearning, which should help them to reflect on their role in promoting better and more effective learning among their students.

Given the diversity of findings from the different studies into the CSFs for e-learning, there is scope for considerable further research, to ascertain the factors that contribute to this diversity. It would, for instance, be useful if researchers were to build a stronger knowledge base around the factors associated with the success of e-learning amongst specific student groups (e.g. first year undergraduates) or within specific countries. In addition, qualitative studies would have the potential to develop a deeper understanding of the experience of e-learning. They might offer insights into the resources and support that academic staff and students find the most helpful, and into the impact of context (such as 'on campus' and distance learning) on elearning success. More specifically, Saudi Arabia, like other countries, has its own traditions, culture, and context; it would be beneficial to explore further the extent to which these aspects influence the implementation, adoption, and CSF's of eLearning systems. 


\section{References}

Abdel-Gawad, T., \& Woollard, J. (2015). Critical success factors for implementing classless e-learning systems in the Egyptian higher education. International Journal of Instructional Technology and Distance Learning, 12 (4), 29-36.

Abouzahra, M. (2011). Building the E-learning System in King Saud University, A System Perspective. In Proceedings of the World Congress on Engineering and Computer Science (Vol. 2. , 1-3). San Francisco, USA. Retrieved from: http://www.iaeng.org/publication/WCECS2011/WCECS2011_pp1176-1178.pdf (April 10, 2017)

Ahmed, T. T. (2013). Toward Successful E-Learning Implementation in Developing Countries: A Proposed Model for Predicting and Enhancing Higher Education Instructors' Participation. International Journal of Academic Research in Business and Social Sciences, 3(1), 422-435.

Alhabeeb, A., \& Rowley, J. (2017). Critical success factors for eLearning in Saudi Arabian universities. International Journal of Educational Management, 31(2), 131-147.

Alhomod, S., \& Shafi, M. M. (2013). Success factors of e-learning projects: A technical perspective. TOJET: The Turkish Online Journal of Educational Technology, 12(2), 247253.

Altameem, A. (2013). What drives successful e-learning: An empirical investigation of the key technical issues in Saudi Arabian Universities. Journal of Theoretical and Applied Information Technology, 53(1), 63-70.

Aljubaili, A. (2014). Saudi Arabia-Dramatic developments in higher education. QS Showcase.

Al-Dosari, H. (2011). Faculty members and students perceptions of e-learning in the English department: A project evaluation. Journal of Social Sciences, 7(3), 391-407.

Bhuasiri, W., Xaymoungkhoun, O., Zo, H., Rho, J. J., \& Ciganek, A. P. (2012). Critical success factors for e-learning in developing countries: A comparative analysis between ICT experts and faculty. Computers \& Education, 58(2), 843-855. 
Boateng, R., Mbrokoh, A. S., Boateng, L., Senyo, P. K., \& Ansong, E. (2016). Determinants of e-learning adoption among students of developing countries. The International Journal of Information and Learning Technology, 33(4), 248-262.

FitzPatrick, T. (2012). Key Success Factors of eLearning in Education: A Professional Development Model to Evaluate and Support eLearning. https://eric.ed.gov/?id=ED537174.

Fryan, L. B., \& Stergioulas, L. (2011). Critical Success Factors for the Adoption of eLearning in the Kingdom of Saudi Arabia Educational Institutions. In Proceedings of 10th European Conference on e-Learning ECEL-2011 (pp. 53-62).

Garrison, D. R. (2011). E-learning in the 21st century: A framework for research and practice. Taylor \& Francis.

González-Gómez, F., Guardiola, J., Rodríguez, Ó. M., \& Alonso, M. Á. M. (2012). Gender differences in e-learning satisfaction. Computers \& Education, 58(1), 283-290.

King, E., \& Boyatt, R. (2015). Exploring factors that influence adoption of e-learning within higher education. British Journal of Educational Technology, 46(6), 1272-1280.

KSU (2010). KSU officials receive United Nations Public Service Award in Barcelona ceremony. Online. Available at: http://news.ksu.edu.sa/en/node/101790

KSU (2017). About KSU. Online. Available at: http://ksu.edu.sa/en/about-ksu

Leidecker, J. K., \& Bruno, A. V. (1984). Identifying and using critical success factors. Long Range Planning, 17(1), 23-32.

Masrom, M. B. (2008). Critical success in e-learning: an examination of technological and institutional support factors. International Journal of Cyber Society and Education, 1(2), 131-142.

Menchaca, M. P., \& Bekele, T. A. (2008). Learner and instructor identified success factors in distance education. Distance Education, 29(3), 231-252.

Mohammadyari, S., \& Singh, H. (2015). Understanding the effect of e-learning on individual performance: The role of digital literacy. Computers \& Education, 82(3), 11-25. 
Mosakhani, M., \& Jamporazmey, M. (2010, September). Introduce critical success factors (CSFs) of elearning for evaluating e-learning implementation success. In Educational and Information Technology (ICEIT), 2010 International Conference on (Vol. 1, pp. V1-224). IEEE.

Musa, M. A., \& Othman, M. S. (2012). Critical success factor in e-Learning: an examination of technology and student factors. International Journal of Advances in Engineering \& Technology, 3(2), 140-148.

Naveed, Q. N., Muhammad, A., Sanober, S., Qureshi, M. R. N., \& Shah, A. (2017). A Mixed Method Study for Investigating Critical Success Factors (CSFs) of E-Learning in Saudi Arabian Universities. Methods, 8(5), 171-178.

Paechter, M., Maier, B., \& Macher, D. (2010). Students' expectations of and experiences in e-learning: Their relation to learning achievements and course satisfaction. Computers \& education, 54(1), 222-229.

Puri, G. (2012). Critical success Factors in e-Learning-An empirical study. International Journal of Multidisciplinary Research, 2(1), 149-161.

Sangrà, A., Vlachopoulos, D., \& Cabrera, N. (2012). Building an inclusive definition of elearning: An approach to the conceptual framework. The International Review of Research in Open and Distributed Learning, 13(2), 145-159.

Selim, H. M. (2007). E-learning critical success factors: an exploratory investigation of student perceptions. International Journal of Technology Marketing, 2(2), 157-182.

Selim, H.M. (2007b), “Critical success factors for eLearning acceptance: confirmatory factor models". Computers \& Education, 49 (2), 396-413.

Sun, P-C, Tasi, R.J., Finger, G., Chen, Y-Y., Yeh, D. (2008). What drives a successful eLearning? An empirical investigation of the critical success factors influencing learner satisfaction. Computer \& Education, 50, 1183-1202. 
Taha, M. (2014). Investigating the success of E-learning in secondary schools: The case of the Kingdom of Bahrain (PhD). London: Brunel University. Retrieved from http://bura.brunel.ac.uk/handle/2438/9237 (Jan 9, 2018).

Teo, T., \& Wong, S. L. (2013). Modelling key drivers of e-learning satisfaction among student teachers. Journal of Educational Computing Research, 48(1), 71-95. 